\title{
PENGARUH BUDAYA ORGANISASI DAN KOMPENSASI TERHADAP MOTIVASI KERJA SERTA IMPLIKASINYA TERHADAP KINERJA KARYAWAN DI BANK BTN CABANG BANDUNG
}

\author{
Dian Siti Masitoh, SE.
}

\begin{abstract}
Abstrak
Masalah penelitian ini adalah karyawan Bank BTN Cabang Bandung belum menunjukkan kinerja yang memadai. Fenomena tinggi rendahnya kinerja karyawan tersebut diprediksi oleh tinggi rendahnya variabel-variabel yang mempengaruhinya, yaitu tingkat motivasi kerja karyawan, yang dipicu oleh kuat lemahnya budaya organisasi dan tingkat kompensasi. Penelitian ini menggunakan pendekatan survey dengan jenis verificative explanation research terhadap 133 karyawan. Analisis dan Interpretasi hasil pengolahan data menggunakan analisis deskriptif dan verifikatif (SEM).

Hasil analisis deskriptif menunjukkan bahwa: Kuat lemahnya Budaya Organisasi, yang termasuk pada kategori kuat, dapat direfleksikan dan dibentuk oleh indikator Inovasi dan pengambilan risiko, Perhatian kepada detail, Orientasi hasil, Orientasi orang, Orientasi tim, Agresivitas, dan Kemantapan. Tingkat Kompensasi Karyawan, yang termasuk pada kategori tinggi, dapat direfleksikan dan dibentuk oleh indikator Keadilan Internal, Keadilan Eksternal, dan Keadilan Individu. Tingkat Motivasi Kerja Karyawan, yang termasuk pada kategori tinggi, dapat direfleksikan dan dibentuk oleh indikator Prestasi, Kekuasaan, dan Afiliasi. Tingkat Kinerja Karyawan, yang termasuk pada kategori tinggi, dapat direfleksikan dan dibentuk oleh indikator Disiplin, Penyelesaian Tugas, serta Perilaku Inovatif dan Spontan.

Hasil analisis verifikatif menunjukkan bahwa Kuat lemahnya budaya organisasi memiliki pengaruh positif dan signifikan terhadap tingkat motivasi kerja karyawan. Tingkat kompensasi memiliki pengaruh positif dan signifikan terhadap tingkat motivasi kerja karyawan. Kuat lemahnya budaya organisasi memiliki pengaruh positif dan signifikan terhadap tingkat kinerja karyawan. Tingkat kompensasi memiliki pengaruh positif dan signifikan terhadap tingkat kinerja karyawan. Tingkat motivasi kerja karyawan memiliki pengaruh positif dan signifikan terhadap tingkat kinerja karyawan
\end{abstract}

Kata Kunci: Budaya Organisasi, Kompensasi, Motivasi Kerja, Kinerja Karyawan.

\section{PENDAHULUAN}

Kinerja karyawan yang tinggi merupakan salah satu syarat dalam pencapaian tujuan perusahaan. Pencapaian tujuan perusahaan diperoleh dari upaya perusahaan dalam mengelola sumber daya manusia yang berpotensi agar dapat meningkatkan hasil kerjanya. Pengelolaan sumber daya manusia yang dilakukan perusahaan tercermin dari kinerja karyawan yang dihasilkan dan dari pencapaian tujuan perusahaan.

Manajemen Bank BTN Cabang Bandung dalam menentukan kinerja karyawan dilakukan melalui penilaian kinerja karyawan. Aspek yang dinilai meliputi: (1) sasaran kerja individu: (2) keterampilan kunci; dan (3) kompetensi, dengan pembobotan tertentu sehingga menghasilkan hasil kinerja karyawan dengan klasifikasi A (istimewa), B (Baik), C (cukup) dan D (kurang).

Sasaran kerja individu adalah pernyataan singkat yang menggambarkan sasaran kerja masing-masing individu sesuai dengan tugasnya dan sasaran yang diturunkan dari Rencana Kerja Anggaran Perusahaan. Keterampilan kunci adalah keahlian yang dibutuhkan seorang pegawai sebagai penunjang dalam pencapaian sasaran kerja/tugas utama. Keterampilan kunci meliputi: penyusunan dan pengendalian anggaran; komunikasi lisan; komunikasi tertulis; komunikasi dalam bahasa Inggris; pengetahuan tentang proses bisnis, standar, kebijakan dan 
prosedur BTN; pengetahuan makro ekonomi dan pengaruhnya terhadap BTN; pengetahuan tentang produk dan pelayanan BTN; keahlian bernegosiasi; numerasi; manajemen proyek dan keterampilan menggunakan komputer.

Kompetensi adalah karakteristik yang lebih sering ditujukan oleh pegawai dengan kinerja yang menonjol pada lebih banyak situasi dengan hasil yang lebih baik, meliputi: dorongan berprestasi; pemikiran analitis; pemikiran konseptual; orientasi pelayanan pelanggan; pengembangan orang lain; dampak dan pengaruh; pencairan informasi; inisiatif; integritas; kesadaran organisasi; komitmen organisasi; membina hubungan; kepemimpinan; kerjasama; peduli terhadap keteraturan dan pemikiran strategis.

Hasil survey awal mengenai kondisi kinerja karyawan Bank BTN tahun 2011 menunjukkan jumlah karyawan dengan nilai klasifikasi B memiliki jumlah terbanyak yaitu $88,53 \%$, nilai klasifikasi A sebanyak $10,55 \%$, sedangkan nilai C dan D masing masing sebanyak 0,92\%. Kondisi ini menunjukan bahwa kinerja karyawan belum menunjukan kinerja yang optimal.

Kondisi kinerja karyawan Bank BTN Cabang Bandung, sebagaimana dikemukakan di atas, perlu segera mendapat perhatian khusus, mengingat cabang ini merupakan salah satu cabang utama yang memiliki asset Rp 901 miliar dan share terhadap Bank BTN secara nasional 3,37\% pada tahun 2011, dan jumlah karyawan mencapai 218 pegawai atau 6,44 \% share terhadap Bank BTN secara nasional. Dengan demikian dilihat dari share yang ada baik asset maupun jumlah pegawai Bank BTN cabang Bandung mempunyai andil cukup besar terhadap Bank BTN secara nasional.

Selain memperhatikan kondisi empirik tersebut, urgensi terhadap peningkatan kinerja karyawan Bank BTN Cabang Bandung juga dapat didasarkan pada argumentasi teoretik. Menurut Sedarmayanti (2009:54) kinerja pegawai yang meningkat akan turut mempengaruhi prestasi organisasi yang akhirnya dapat mencapai tujuan organisasi yang diharapkan. Oleh karena itu, merupakan suatu keharusan bagi perusahaan untuk mengembangkan sumber daya manusia sebagai salah satu faktor untuk mewujudkan kinerja karyawan yang optimal.

Belum optimalnya kinerja karyawan memberi peluang bagi penulis untuk melakukan penelitian mengenai faktor-faktor yang mempengaruhi kinerja karyawan. Pendekatan yang digunakan untuk memecahkan masalah rendahnya kinerja karyawan, yaitu menggunakan pendekatan perilaku organisasi. Robbins, S.P. (2006:9) mengatakan bahwa perilaku organisasi adalah "Suatu studi yang mempelajari dampak perorangan, kelompok, proses dan struktur pada perilaku dalam organisasi dengan maksud menerapkan pengetahuan semacam itu untuk memperbaiki keefektivan organisasi".

Berdasarkan perspektif perilaku organisasi, banyak faktor yang dapat mempengaruhi kinerja karyawan. Cardy dan Dobbins (1994); dan Waldman (1994) dalam Williams, R.S., (2006:129), mengelompokkan faktor-faktor yang mempengaruhi kinerja ke dalam dua kategori, yaitu system factors dan person factors. Termasuk ke dalam system factors adalah karakteristik pekerjaan, karakteristik tujuan, karakteristik lingkungan fisik, karakteristik lingkungan sosial, karakteristik peran kerja, dan karakteristik organisasi. Sedangkan yang termasuk person factors, adalah atas kemampuan, kepribadian, pengetahuan deklaratif, pengetahuan prosedural, keterampilan, dan motivasi.

Merujuk kepada pendapat tersebut, penelitian ini hanya mengkaji tiga faktor yang mempengaruhi kinerja karyawan, yaitu: budaya organisasi, kompensasi, dan motivasi. Budaya organisasi dan kompensasi termasuk ke dalam kategori system factors, yang diturunkan dari karakteristik organisasi, sedangkan motivasi merupakan salah satu faktor dari kategori person factors. 


\section{KERANGKA BERPIKIR}

Grand Theory yang dijadikan rujukan untuk memecahkan masalah penelitian adalah teori perilaku organisasi. Luthans (1998), Gibson, et.al. (1996), menjelaskan perilaku individu pada dasarnya dilandasi oleh proses-proses psikis pada diri individu atau organisme di dalam lingkungan tertentu. Luthans (1998:23) melalui kajiannya mengenai perilaku organisasi mengatakan bahwa panduan untuk mempelajari perilaku di dalam organisasi adalah dengan menggunakan pendekatan stimulus-response. Model ini kemudian dikembangkan Luthans menjadi S-O-BC (Stimulus-Organisme-Behavior-Consequences) dengan asumsi yang sama dengan model S-O-R. Kelebihan yang diberikan model S-O-B-C adalah adanya consequences yang menunjukkan orientasi yang akan dicapai melalui perilaku kerja. Luthans (1998:23) menggambarkan kerangka konseptual S-O-B-C, seperti tampak pada Gambar 1.
Stimulus (S) dalam model di atas mewakili segala sesuatu yang berada dalam lingkungan organisasi sebagaimana dapat diamati, dihayati dan dialami, yang menjadi stimulus bagi organisme atau individu (O). Individu akan berinteraksi dengan stimulus yang akan menimbulkan persepsi atau interpretasi tentang stimulus (S). Hasil interpretasi stimulus (S) akan melahirkan perilaku (B) tertentu yang akan menimbulkan hasil perilaku atau konsekuensikonsekuensi (C) tertentu. Model tersebut menunjukkan bahwa perilaku tergantung pada individu dan lingkungan yang dihadapinya. Artinya, individu dan lingkungan akan selalu berada dalam satu hubungan yang tidak terpisah. Di samping itu, Luthans (1998) menyatakan secara eksplisit terjadi umpan balik antara perilaku (B) dan hasil perilaku (C) atau antara perilaku (B) dengan organisme (O). Hal ini mengandung arti individu akan mengalami proses belajar sosial dari hasil perilaku yang diperolehnya.

\section{STIMULUS SITUATION}

\section{ORGANISM/PERSON}

\begin{tabular}{|c|c|c|c|c|}
\hline $\begin{array}{l}\text { EXTERNAL ENVIRONMENT } \\
\text { SENSUAL STIMULATION } \\
\text { PHYSICAL ENVIRONMENT } \\
\text { Office } \\
\text { Factory Floor } \\
\text { Research Laboratory } \\
\text { Store } \\
\text { Climate } \\
\text { Etc. } \\
\text { Social Cultural Environment } \\
\text { Management Style } \\
\text { Value } \\
\text { Discrimination } \\
\text { Etc. }\end{array}$ & $\begin{array}{l}\text { Confrontation } \\
\text { of Special } \\
\text { Stimulus (e.q. } \\
\text { Supervisor or } \\
\text { New } \\
\text { Procedure) }\end{array}$ & $\begin{array}{l}\text { Registration } \\
\text { of Stimulus } \\
\text { (e.q. Sensory } \\
\text { and neural } \\
\text { mechanism) }\end{array}$ & 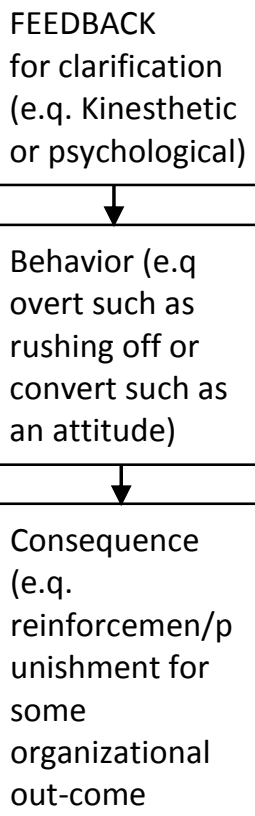 & CONSEQUENCE \\
\hline
\end{tabular}

\section{Gambar 1.}


Model psikologi tentang konsep dasar perilaku individu jika diadaptasikan dalam kehidupan organisasi dapat dilihat pada Gambar 1.

Gambar 1 menunjukkan bahwa antara individu dengan organisasi terjadi interaksi yang dapat menimbulkan persepsi atau interpretasi tentang lingkungan organisasi yang dihadapinya. Hasil interpretasi itu kemudian akan menimbulkan perilaku tertentu dari anggota organisasi. Perilaku tersebut pada gilirannya akan menentukan hasil tertentu yang dalam konteks organisasi disebut efektivitas organisasi.

Perilaku dan hasil perilaku atau efektivitas organisasi akan memberikan umpan balik kepada individu sebagai tanda adanya proses belajar sosial. Umpan balik juga terjadi dari hasil perilaku atau efektivitas organisasi terhadap organisasi. Dalam konteks organisasi, umpan balik ini mengandung arti bahwa efektivitas organisasi yang dicapai digunakan sebagai informasi untuk melakukan berbagai perbaikan dalam mengelola segala sesuatu yang ada dalam organisasi.

Merujuk kepada uraian tersebut dapat dikemukakan bahwa efektivitas organisasi ditentukan oleh perilaku individu dalam organisasi. Artinya, jika perilaku individu dalam organisasi memperlihatkan kinerja yang tinggi sesuai dengan tuntutan organisasi, maka organisasi akan menjadi efektif. Sebaliknya, jika perilaku individu dalam organisasi memperlihatkan kinerja yang rendah, maka organisasi akan sulit mencapai tingkat efektivitas yang diharapkan. Uraian ini sesuai dengan pendapat Gibson, et al. (1996:13) yang menegaskan bahwa kinerja individu adalah dasar kinerja organisasi.

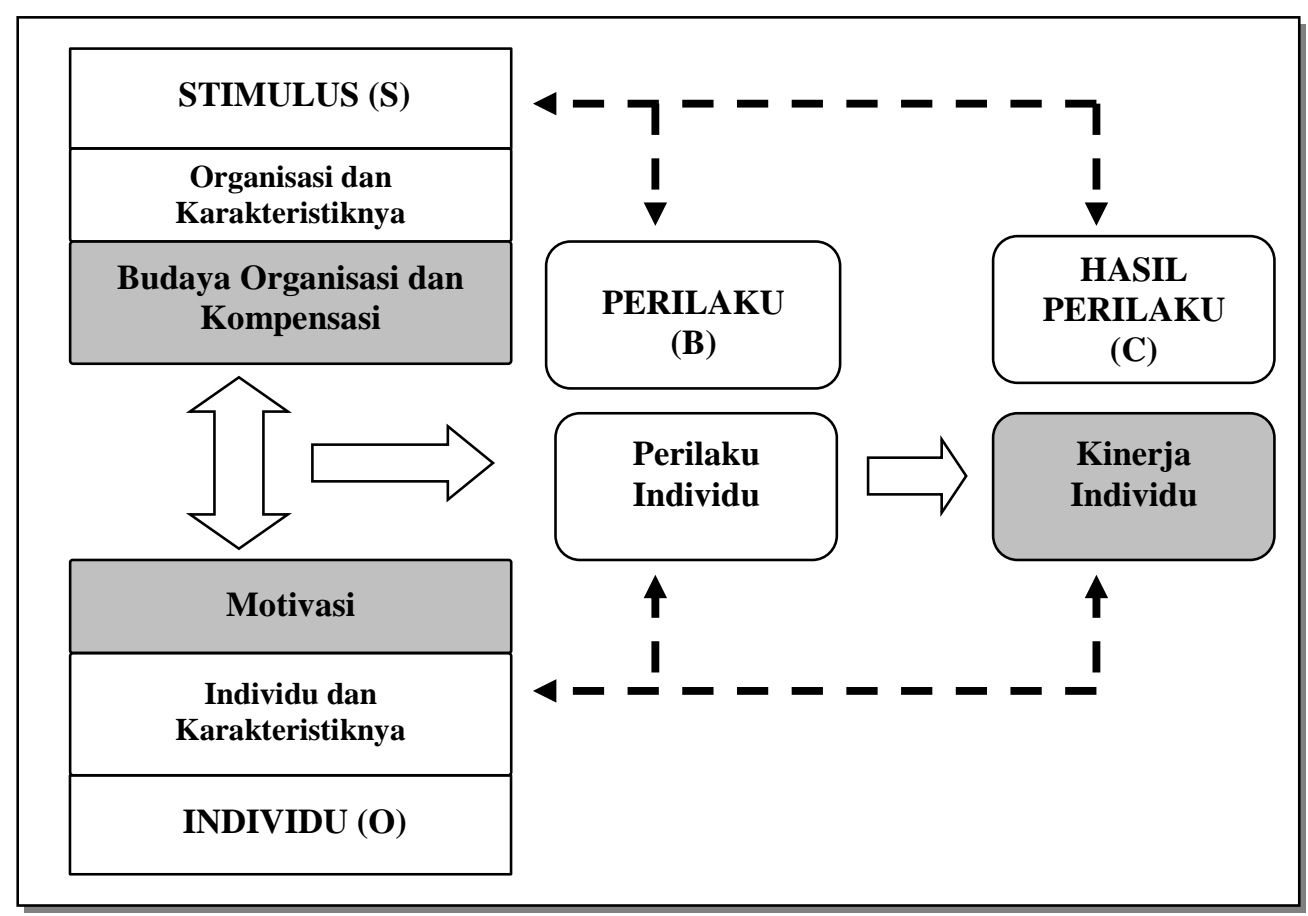

Gambar 2

Perilaku Individu dalam Konteks Perilaku Organisasi

Sumber: Diadaptasi dari Luthans (1998) 
Kinerja individu dalam hal ini kinerja karyawan merupakan inti kajian dari penelitian ini. Rivai, V. (2004:14) mengemukakan kinerja adalah hasil atau tingkat keberhasilan seseorang secara keseluruhan selama periode tertentu di dalam melaksanakan tugas dibandingkan dengan berbagai kemungkinan, seperti standar hasil kerja, target atau sasaran atau kriteria yang telah ditentukan terlebih dahulu dan telah disepakati bersama. Brown (dalam Rahardja, 2004) mengemukakan bahwa kinerja adalah manifestasi konkret dan dapat diobservasi secara terbuka atau realisasi suatu kompetensi. Dengan demikian yang dimaksud dengan kinerja karyawan dalam penelitian ini adalah unjuk kerja karyawan dalam melaksanakan tugasnya sebagai realisasi konkret dari kompetensi yang dimilikinya berdasarkan kecakapan, pengalaman dan kesungguhan. Merujuk kepada pendapat Simamora (2004:339), kinerja individu dapat diukur melalui indikator meliputi: 1) disiplin; 2) penyelesaian tugas (efektivitas); dan 3) perilaku inovatif dan spontan.

Banyak faktor yang mempengaruhi kinerja individu. Cardy dan Dobbins (1994); dan Waldman (1994) dalam Williams, R.S., (2006:129), mengembangkan model faktorfaktor yang mempengaruhi kinerja. Model tersebut berupaya menggabungkan dua perspektif mengenai kinerja, yaitu perspektif hasil dan perspektif perilaku. Dalam model tersebut terdapat dua kategori kinerja, yaitu work outcomes dan job-relevant behaviors. Work outcome ditentukan oleh system factors dan job-relevant behaviors. Hubungan person factors dengan work outcomes, tidak langsung tetapi beroperasi melalui job-relevant behaviors. Hubungan ini ditunjukkan diagram pada Gambar 3

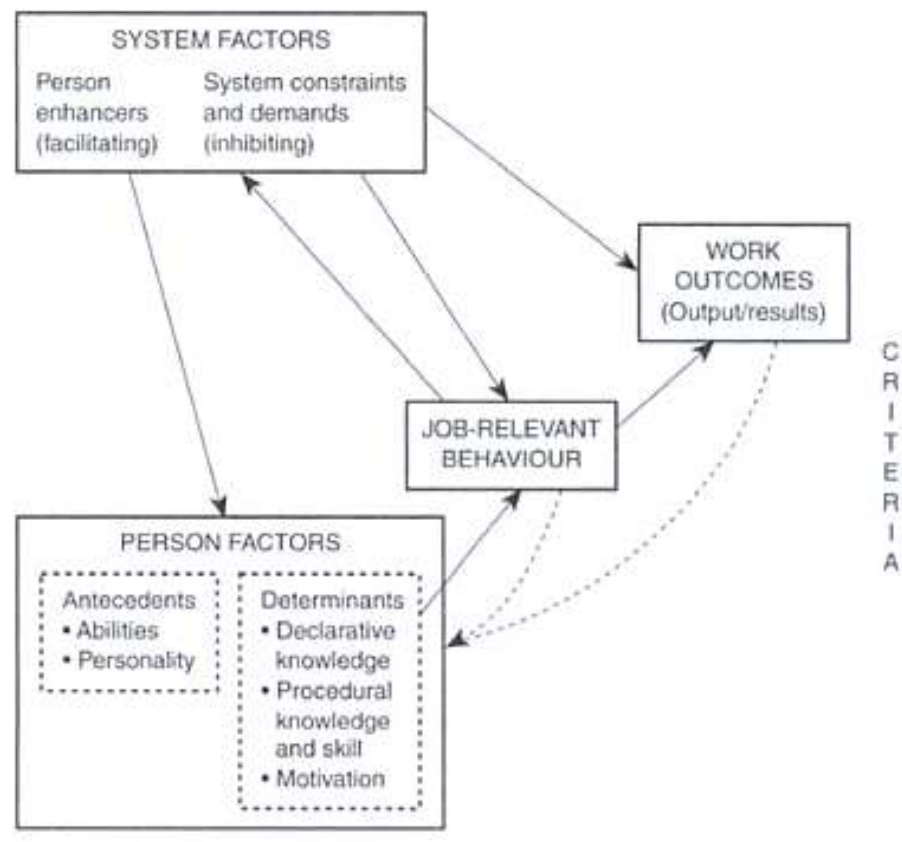

Gambar 3

Faktor Determinan Kinerja

Sumber: Williams, R.S., (2006:130) 
Faktor individu (person factors) terdiri atas dua kelompok yaitu antecedents dan determinants. Faktor antecedents terdiri atas abilities dan personality, sedangkan faktor determinants, terdiri atas declarative knowledge, procedural knowledge and skill, dan motivation. Faktor sistem (system factors) terdiri atas person enhancer dan system constraints and demands. Daftar rinci mengenai system factor ditunjukkan pada Tabel 1.

Tabel 1

Daftar Rincian System Factor yang Mempengaruhi Kinerja Individu

\begin{tabular}{|c|}
\hline TASK CHARACTERISTICS \\
\hline - Consistency of task \\
\hline - Stage of skill acquisition with respect to task \\
\hline - Amount of task structure \\
\hline - $\quad$ Time on task \\
\hline - Amount of time pressure to complete task \\
\hline - Skill variety, task identity, task significance, autonomy and feedback \\
\hline Goal characteristics \\
\hline - $\quad$ Specificity \\
\hline - Complexity \\
\hline - Difficulty \\
\hline - Rewards associated with goal attainment \\
\hline - $\quad$ Conflict with other goals \\
\hline - $\quad$ Performance versus mastery goal \\
\hline Characteristics of physical environment \\
\hline - Ambient conditions (e.g. light, noise, heat) \\
\hline - $\quad$ Time of day \\
\hline - Danger of bodily harm \\
\hline $\begin{array}{l}\text { - Workplace layout (e.g. open-plan office versus non-open-plan office, amount of privacy at } \\
\text { workstation) }\end{array}$ \\
\hline - Work locus (home versus office) \\
\hline Characteristics of work role \\
\hline - $\quad$ Role ambiguity \\
\hline - $\quad$ Rote overload \\
\hline - Rote conflict \\
\hline Characteristics of social environment \\
\hline - $\quad$ Personality of co-workers (supervisors, subordinates and peers) \\
\hline - Management style of immediate supervisor (e.g. autocratic versus democratic) \\
\hline - Cohesiveness of work group \\
\hline - Amount of social support from co-workers, friends and family \\
\hline - Work primarily in groups versus work primarily independently \\
\hline Characteristics of organization \\
\hline - Organizational values \\
\hline - Organizational reward systems \\
\hline
\end{tabular}


- Level of employee ownership in organization

- Amount of organizational instability (e.\& rapid changes in leadership, downsizing, growth)

- Nature of administrative policies and procedures (e.g. level of bureaucracy)

- Organizational structure (e.g. matrix versus hierarchical)

Sumber: Williams, R.S., (2006:132)

Penelitian ini tidak mengkaji seluruh faktor yang mempengaruhi kinerja sebagaimana dikemukakan Cardy dan Dobbins (1994); dan Waldman (1994) dalam Williams, R.S., (2006:129). Penelitian ini hanya mengkaji faktor budaya organisasi, kompensasi, dan motivasi.

Budaya organisasi menurut Robbins, S.P. (2006:256) merupakan sistem makna bersama terhadap nilai-nilai primer yang dianut bersama dan didukung organisasi. Budaya organisasi akan memberikan suasana yang dapat mendukung karyawan untuk dapat melakukan pekerjaan dengan baik. Budaya organisasi yang dijalankan oleh jajaran karyawan dengan konsekuen dan konsisten dapat menciptakan kehidupan organisasi yang terbuka, karyawan bebas mengungkapkan pikiran dan perasaan, serta berpartisipasi dalam proses pengambilan keputusan manajerial. Semua ini akan memberikan pengaruh positif terhadap kinerja karyawan yang selanjutnya akan berpengaruh terhadap kinerja organisasi. Berdasarkan uraian di atas, budaya organisasi merupakan faktor yang dapat mempengaruhi kinerja karyawan. Secara kerangka konseptual, Robbins (2006:545) melihat bagaimana hubungan budaya organisasi berdampak pada kinerja, seperti tampak pada Gambar 4

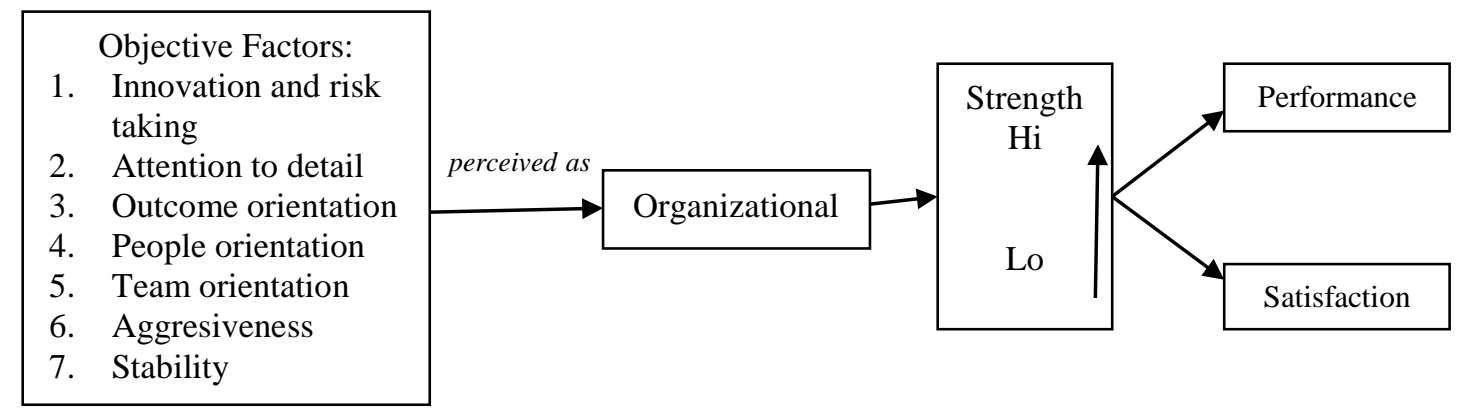

\section{Gambar 4}

Hubungan Budaya Organisasi terhadap Kinerja Karyawan

Sumber: Robbins, S.P. (2006:545)

Berdasarkan Gambar 4 penggunaan faktorfaktor objektif yang akan berpengaruh terhadap lingkungan organisasi meliputi: 1) inovasi dan pengambilan risiko; 2) perhatian pada kerincian; 3) orientasi hasil; 4) orientasi orang; 5) orientasi tim; 6) keagresifan; dan 7) kemantapan. Jika seluruh faktor objektif tersebut melekat kuat dan bernilai positif, maka akan berpengaruh terhadap kinerja karyawan, begitu juga sebaliknya.

Kompensasi merupakan balas jasa yang diberikan oleh perusahaan kepada karyawan berupa uang maupun barang atas keterlibatan karyawan dalam pencapaian tujuan perusahaan. Menurut Gary Dessler (dalam Tjutju Yuniarsih dan Suwatno, 2008:125) "Kompensasi merupakan semua bentuk penggajian atau 
ganjaran yang mengalir kepada pegawai atau timbul dari kepegawaian mereka".

Menurut Ivancevich (dalam Amos, T. L., et. Al., 2009:311), tujuan (objective) dari kompensasi adalah menciptakan sistem imbalan yang memenuhi kebutuhan karyawan dan perusahaan. Sedangkan dampak (outcome) yang diharapkan dari kompensasi adalah karyawan tertarik untuk bekerja dan termotivasi untuk melakukan pekerjaan dengan baik. Oleh karena itu keadilan dalam kompensasi menjadi krusial bagi peningkatan kinerja karyawan.

Dalam terminologi manajemen sumber daya manusia menurut Ruysseveldt, J.V, and Harzing, A.W. (2005:309), keadilan (equity) dalam kompensasi didefinisikan sebagai perbandingan relatif kompensasi yang diterima karyawan dengan pekerjaan yang dilakukannya. Keadilan kompensasi menurut Cascio (dalam Amos T.L., at al, 2009:312), dan Erasmus, B., and Schenk, H. (2008:478) dapat dipahami dalam tiga tipe yaitu: keadilan internal, keadilan eksternal, dan keadilan individu. Keadilan internal adalah kesesuaian kompensasi yang diterima karyawan dengan nilai internal masingmasing pekerjaan dalam suatu organisasi. Proses untuk menentukan nilai dan suatu pekerjaan secara relatif terhadap pekerjaan lain dalam suatu organisasi disebut job evaluation. Keadilan eksternal berkaitan dengan kewajaran kompensasi yang diterima karyawan pada pekerjaan tertentu dibandingkan dengan pekerjaan yang serupa di luar organisasi. Informasi mengenai keadilan eksternal ini dapat dilakukan melalui salary survey. Keadilan individu berkaitan dengan sejauh mana kompensasi karyawan merupakan refleksi dari kontribusinya pada organisasi, misalnya didasarkan pada kinerja, kompetensi, atau senioritas. Keadilan individu dapat diperoleh melalui informasi yang diperoleh dari penilaian prestasi kerja (performance appraisal).

Mathis, R.L., dan Jackson, J.H. (2012:171) mengemukakan kompensasi memiliki kaitan yang erat dengan kinerja individu, kelompok atau organisasi. Oleh karena itu karyawan yang berkinerja lebih baik harus menerima kompensasi lebih. Sims, R.R. (2007:272) menegaskan sistem penghargaan organisasi (kompensasi) adalah salah satu kekuatan yang paling kuat sebagai pendorong perilaku karyawan (kinerja). Selaras dengan pendapat tersebut Rivai, V. (2004:357) mengungkapkan bila kompensasi yang dirasakan oleh karyawan kurang, maka akan mengurangi kinerja, meningkatkan keluhan-keluhan penyebab mogok kerja dan mengarah pada tindakantindakan fisik dan psikologis, seperti meningkatnya derajat ketidakhadiran dan perputaran karyawan.

Sedarmayanti (2009:23) mengungkapkan bahwa "Besar kecilnya kompensasi dapat mempengaruhi prestasi kerja, motivasi dan kepuasan kerja". Adanya kompensasi yang memadai dapat membuat karyawan termotivasi untuk bekerja dengan baik, dan dapat meningkatkan kinerjanya seperti yang diharapkan perusahaan. Hal ini akan memudahkan pencapaian tujuan perusahaan. Hasibuan, M.S.P. (2000:112) mengungkapkan kebijakan kompensasi baik besarnya, susunannya maupun waktu pembayarannya dapat mendorong gairah kerja dan keinginan karyawan untuk mencapai prestasi kerja yang optimal, sehingga membantu terwujudnya sasaran perusahaan. Kriteria-kriteria dari pemberian kompensasi harus mencakup: 1) gaji; 2) insentif; 3) tunjangan; dan 4) fasilitas.

Hoy dan Miskel (2001) meyakini bahwa salah satu cara yang baik untuk mendapatkan gambaran mengenai individu adalah dengan mengkaji motivasi mereka. Motivasi dalam penelitian ini mengacu pada McClelland's Achievement Motivation Theory atau Teori Motivasi Prestasi. McClelland (Aswathappa, K., 2007:364). mengelompokkan kebutuhan manusia ke dalam tiga jenis kebutuhan, yaitu (1) Need for achievement, (2) Need for power, (3) Need for affiliation. Need for achievement (keberhasilan) merupakan kebutuhan manusia 
yang dapat memunculkan motivasi. Keberhasilan manusia dalam memenuhi/memuaskan kebutuhannya dapat memunculkan motivasi. Need for power (kekuasaan), seseorang membutuhkan kekuasaan untuk mempengaruhi orang lain. Serendah apapun kedudukan/jabatan seseorang dalam suatu organisasi ia tetap ingin berkuasa dan berpengaruh terhadap yang lainnya. Need for affiliation (afiliasi), sebagai makhluk sosial kebutuhan afiliasi merupakan kebutuhan manusia yang penting untuk dipuaskan. Seperti kebutuhan/keinginan untuk disenangi, dicintai, dapat bekerja sama, bersahabat, dan saling mendukung dalam kegiatan organisasi, adalah merupakan bentuk-bentuk pemuasan kebutuhan manusia dalam hidup bermasyarakat.

Winardi (2002:2) menjelaskan konsep motivasi merupakan sebuah konsep penting dalam studi tentang kinerja individu. Dengan perkataan lain motivasi merupakan sebuah determinan penting bagi kinerja individual. Sekaran (dalam Pattanayak, B., 2005:188) menggambarkan keterkaitan antara motivasi dengan kinerja seperti tampak pada Gambar 5

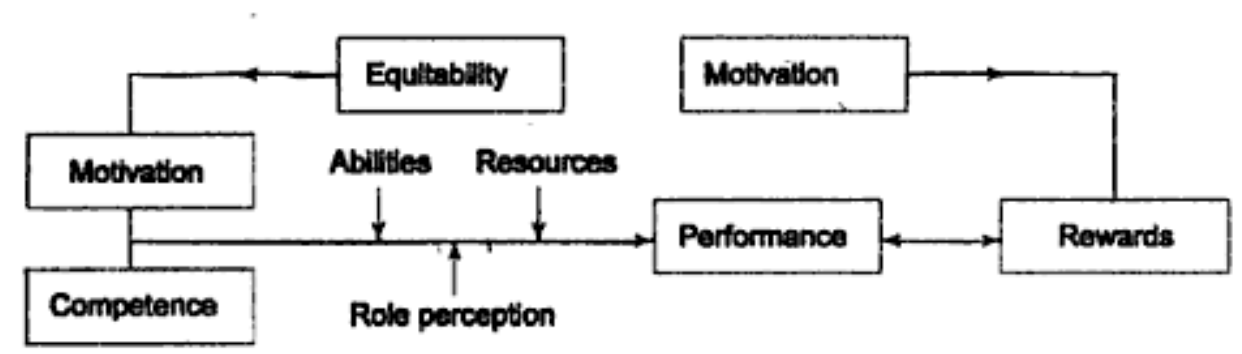

Gambar 5

Keterkaitan Motivasi dan Kinerja Model Sekaran

Sumber: Pattanayak, B. (2005:188)

Faktor budaya organisasi, kompensasi, dam motivasi selain memiliki pengaruh terhadap kinerja karyawan, ketiga faktor tersebut juga memiliki keterkaitan satu sama lain. Deb, T. (2009:269) mengemukakan budaya organisasi berpengaruh terhadap sistem manajemen dan manajemen kompensasi. Sebab menurut Aswathappa, K., dan Dash, S. (2008:235) baik kompensasi yang ditetapkan berdasarkan senioritas maupun yang ditetapkan berdasarkan kinerja, umumnya ditentukan berdasarkan budaya organisasi. Oleh karena itu budaya organisasi memiliki pengaruh yang kuat terhadap kompensasi.

Berdasarkan perspektif ilmu sosial, penggunaan symbol, sagas, dan stories menurut Richard, M.A., et al. (2009:41) merupakan komponen utama dari budaya organisasi.
Sementara itu symbol memiliki peranan penting untuk mengontrol dan memotivasi setiap sistem sosial. Menurut Kono, T., dan Clegg, S.R (1998:106), motivasi merupakan salah satu elemen dari budaya organisasi. Divedi, R. K. (1995:30), mengemukakan motivasi dapat dibentuk melalui interaksi antara sikap dan situasi (Motivation $=$ Attitude $X$ Situation). Situasi yang dimaksud merujuk pada budaya organisasi. Nelson, D.L. dan Quick, J.C. (2008:393), menjelaskan salah satu fungsi dari budaya organisasi adalah memberikan identitas dan meningkatkan komitmen anggota organisasi. Ketika nilai-nilai perusahaan terinternalisasi pada karyawan, secara instrinsik mereka akan menemukan identitas diri sendiri dan identitas dengan sesama pekerja. Kondisi seperti ini dapat meningkatkan motivasi dan 
komitmen karyawan. Dengan demikian, budaya organisasi dapat mempengaruhi motivasi karyawan.

Terkait dengan pengaruh kompensasi terhadap motivasi, McLaughlin, D.J., (1991:59) mengemukakan kompensasi dapat melemahkan motivasi. Hal ini didasarkan pada tesis Frederick Herzberg yang menyatakan bahwa faktor-faktor seperti achievement, recognition, the work itself, dan advancement dapat menstimulasi karyawan, sedangkan faktor lainnya menyebabkan ketidakpuasan. Herzberg mengategorikan gaji sebagai sumber utama ketidakpuasan. Penelitian berikutnya menunjukkan bahwa sebagian besar faktorfaktor tersebut dapat memotivasi atau menurunkan motivasi, tergantung pada situasi.

Ivancevich, (dalam Amos, T.L., et.al., 2009:311), menjelaskan kebijakan kompensasi dibutuhkan dalam organisasi apapun. Tujuan dari setiap fungsi kompensasi adalah untuk menciptakan suatu sistem imbalan yang memenuhi kebutuhan perusahaan dan karyawan. Hasil yang diharapkan adalah karyawan yang tertarik untuk bekerja dan termotivasi untuk melakukan pekerjaan dengan baik. Oleh karena itu menurut Amos, T.L., et.al.
(2009:311) kompensasi harus dikelola secara efektif. Kompensasi merupakan komponen biaya terbesar bagi bisnis dan dapat mempengaruhi tidak hanya posisi kompetitif, tetapi juga dapat mempertahankan tenaga kerja.

Pemaparan di atas merupakan kerangka berpikir dari penelitian ini. Berdasarkan hal tersebut dapat digambarkan model kausal variabel penelitian seperti tampak pada Gambar 6.

Merujuk pada kerangka berfikir, maka hipotesis yang penulis ajukan dalam penelitian ini adalah: (1) Kuat lemahnya budaya organisasi berpengaruh positif terhadap tingkat motivasi kerja karyawan di Bank BTN Cabang Bandung; (2) Tingkat kompensasi berpengaruh positif terhadap tingkat motivasi kerja karyawan di Bank BTN Cabang Bandung; (3) Kuat lemahnya budaya organisasi berpengaruh positif terhadap tingkat kinerja karyawan di Bank BTN Cabang Bandung; (4) Tingkat kompensasi berpengaruh positif terhadap tingkat kinerja karyawan di Bank BTN Cabang Bandung; dan (5) Tingkat motivasi kerja karyawan berpengaruh positif terhadap tingkat kinerja karyawan di Bank BTN Cabang Bandung.

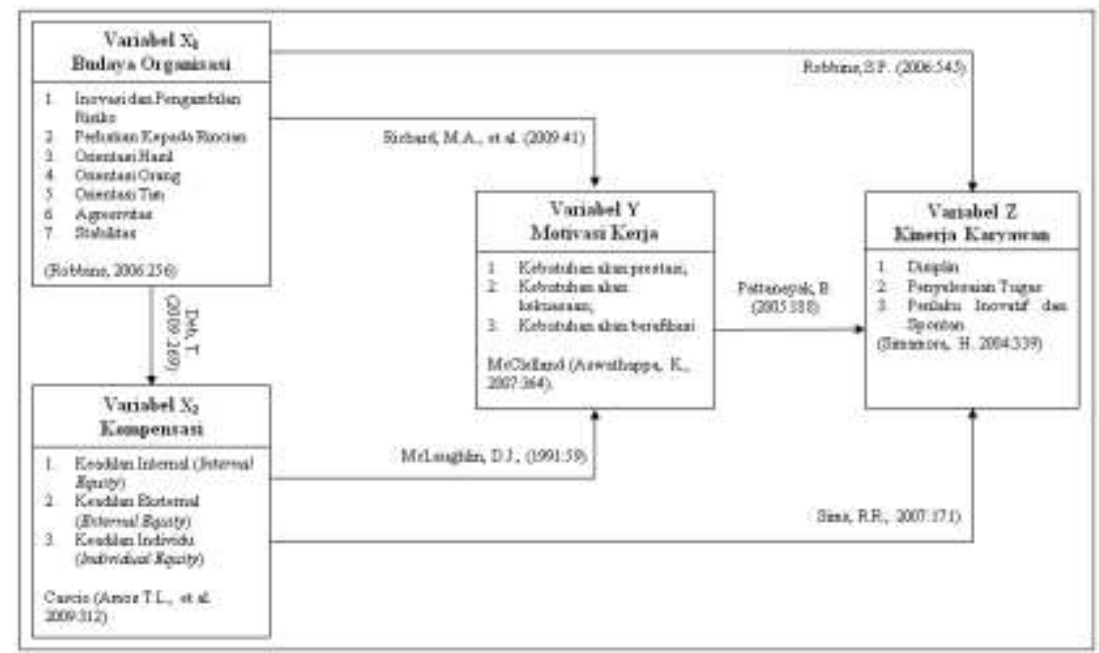

Gambar 6

Model Kausal Variabel Penelitian 


\section{METODOLOGI}

Penelitian ini merupakan tipe penelitian verifikatif yaitu penelitian yang bertujuan menguji hipotesis. Sesuai dengan tujuan penelitian yang hendak dicapai, metode yang digunakan adalah Explanatory Survey Method, yakni suatu metode penelitian survey yang bertujuan menguji hipotesis dengan cara mendasarkan pada pengamatan terhadap akibat yang terjadi dan mencari faktor-faktor yang mungkin menjadi penyebab melalui data tertentu (Rusidi, 1989:19). Konsekuensi metode penelitian ini memerlukan operasionalisasi variabel-variabel yang dapat diukur secara kuantitatif sedemikian rupa untuk dapat digunakan model uji hipotesis dengan metode statistika. Metode ini digunakan antara lain karena alasan sebagai berikut: (1) Tidak semua anggota populasi dijadikan sampel; (2) Unit analisa bersifat individual; dan (3) Pendekatan yang digunakan adalah pendekatan kuantitatif.

Mengingat masalah yang diteliti adalah gejala sosial, maka gambaran yang diperoleh di samping menggunakan pendekatan analisis kuantitatif berdasarkan informasi statistik juga digunakan pendekatan analisis kualitatif yang didasarkan kepada interpretasi terhadap hasilhasilnya.

Populasi dalam penelitian ini adalah seluruh karyawan yang bekerja di BTN Cabang Bandung, yaitu sebanyak 200. Teknik sampling yang digunakan dalam penelitian ini adalah teknik random sampling. Ukuran sampel dihitung berdasarkan formulasi yang dikemukakan Slovin (dalam Umar, H., 2003:141). Dengan menggunakan rumus tersebut diperoleh ukuran sampel sebanyak 133 orang pegawai.

Teknik pengumpulan data yang digunakan dalam penelitian ini adalah kuesioner. Digunakannya teknik pengumpulan data melalui kuesioner sejalan dengan metode yang digunakan dalam penelitian ini. Dikatakan oleh Rusidi (1989:16) bahwa "ciri lainnya dari pendekatan survey explanatory adalah pengumpulan informasi diambil dari sampel atas populasi dengan menggunakan kuesioner sebagai alat pengumpul datanya".

Dalam menganalisis dan menginterpretasikan hasil pengolahan data, digunakan analisis deskriptif dan analisis verifikatif. Analisis deskriptif digunakan untuk menggambarkan karakteristik variabel penelitian, sedangkan verifikatif digunakan untuk menguji hipotesis penelitian dengan menggunakan uji statistik yang relevan yaitu statistik deskriptif dan structural equation model (SEM) untuk menguji hipotesis asosiatif.

\section{HASIL PENELITIAN}

\subsection{Uji Persyaratan Data}

Sebelum menganalisis Structural Equation Model (SEM), terlebih dahulu dilakukan uji persyaratan data. Uji persyaratan data ini terdiri atas uji normalitas, uji linieritas, dan uji homogenitas. Hasil pengujian normalitas data menggunakan one-sample Kolmogorov-Smirnov test menunjukkan bahwa nilai signifikansi untuk setiap variabel berada di atas nilai kritis 0,05. Dengan demikian dapat disimpulkan semua data berdistribusi normal. Pengujian linieritas dilakukan dengan menggunakan uji regresi linear berganda. Hasil pengujian linieritas menunjukkan bahwa nilai F-hitung adalah sebesar 64,037 dengan signifikansi 0,000 yang berarti bahwa masing-masing variabel bebas bersifat linier. Pengujian homogenitas dilakukan dengan menggunakan uji one-way ANOVA. Hasil pengujian homogenitas menunjukkan bahwa setiap variabel memiliki signifikansi 0,000 yang berarti bahwa setiap variabel memiliki sifat homogen. 


\subsection{Uji Persyaratan Data}

Secara keseluruhan model pengaruh kuat lemahnya budaya organisasi, tingkat kompensasi, tingkat motivasi kerja terhadap tingkat kinerja karyawan di Bank BTN Cabang Bandung dapat digambarkan pada Gambar 7

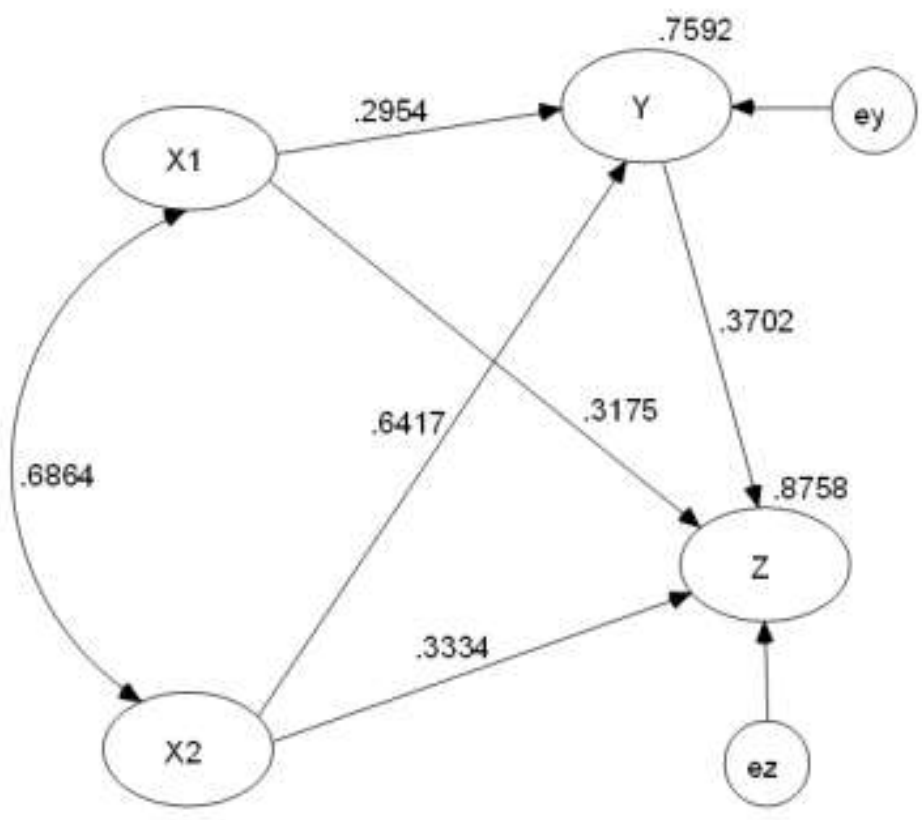

Gambar 7

Model Struktural Pengaruh Kuat lemahnya Budaya Organisasi dan Tingkat Kompensasi melalui Tingkat Motivasi Kerja Karyawan terhadap Tingkat Kinerja Karyawan dengan Koefisien Terstandarkan

Berdasarkan model struktural tersebut, terdapat lima hipotesis yang diuji, yaitu: (1) Kuat lemahnya budaya organisasi berpengaruh positif terhadap tingkat motivasi kerja karyawan di Bank BTN Cabang Bandung; (2) Tingkat kompensasi berpengaruh positif terhadap tingkat motivasi kerja karyawan di Bank BTN Cabang Bandung; (3) Kuat lemahnya budaya organisasi berpengaruh positif terhadap tingkat kinerja karyawan di Bank BTN Cabang Bandung; (4) Tingkat kompensasi berpengaruh positif terhadap tingkat kinerja karyawan di Bank BTN Cabang Bandung; dan (5) Tingkat motivasi kerja karyawan berpengaruh positif terhadap tingkat kinerja karyawan di Bank BTN Cabang Bandung.
Model struktural tersebut dapat dirumuskan dalam persamaan model struktural sebagai berikut:

$$
Y=0,2954 \times 1+0,6417 \times 2+0,2408 \text { [1, }
$$
dengan $\mathrm{R} 2=0,7592$

$$
Z=0,3175 X 1+0,3334 X 2+0,3702 Y+
$$
0,1242 目2, dengan $R 2=0,8758$

Hasil pengujian overall model fit menunjukkan bahwa nilai-P sebesar 0,2223 signifikan pada tingkat kesalahan 5\%; nilai RMSEA lebih kecil dari 0,08 serta nilai CFI lebih besar dari 0,90. Dengan demikian dapat disimpulkan bahwa model yang diusulkan fit dengan data. Hasil uji kebermaknaan terhadap 
masing-masing parameter persamaan struktural semuanya signifikan pada tingkat kesalahan $5 \%$. Dengan demikian dapat disimpulkan bahwa kelima hipotesis yang diajukan seutuhnya dapat diterima. Artinya, kuat lemahnya budaya organisasi dan tingkat kompensasi berpengaruh positif terhadap tingkat motivasi kerja, serta lemahnya budaya organisasi, tingkat kompensasi, dan tingkat motivasi kerja berpengaruh positif terhadap tingkat kinerja karyawan.

Besarnya pengaruh langsung dari kuat lemahnya budaya organisasi terhadap tingkat motivasi kerja adalah sebesar 0,2954 atau 8,73\%; pengaruh tingkat kompensasi terhadap tingkat motivasi kerja sebesar 0,6417 atau
41,18\%. Besarnya pengaruh langsung dari kuat lemahnya budaya organisasi terhadap tingkat kinerja karyawan adalah sebesar 0,3175 atau 10,08\%; tingkat kompensasi terhadap tingkat kinerja karyawan sebesar 0,3334 atau 11,12\%; dan tingkat motivasi kerja terhadap tingkat kinerja karyawan sebesar 0,3702 atau 13,70\%.

\subsection{Model Pengukuran}

Untuk menjawab masalah penelitian deskriptif, dilakukan uji model pengukuran. Model pengukuran ini pada prinsipnya merupakan uji validitas dan reliabilitas. Berdasarkan perhitungan, model pengukuran pada penelitian ini dapat disajikan pada Gambar 8.

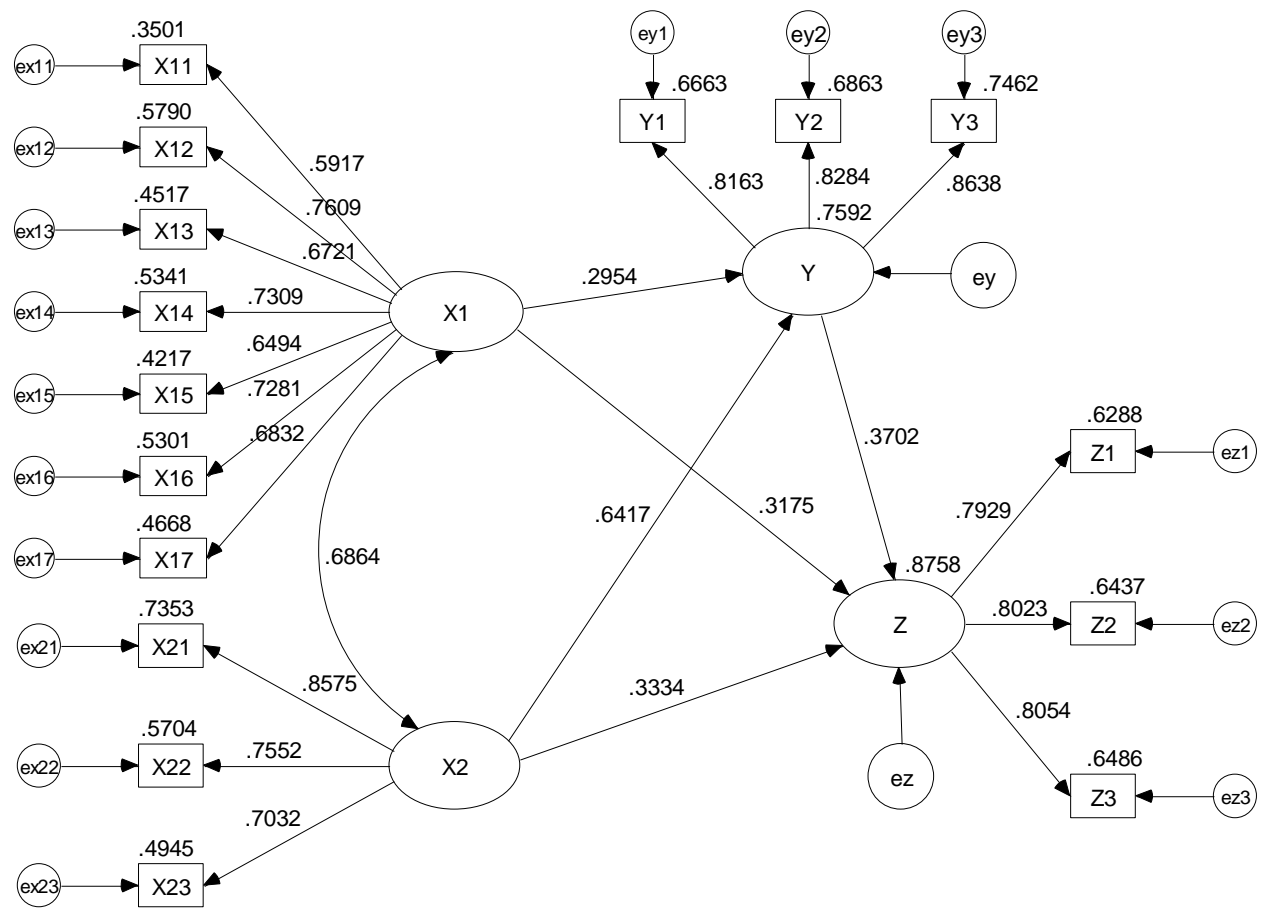

Gambar 8

Model Pengukuran Pengaruh Kuat lemahnya Budaya Organisasi dan Tingkat Kompensasi melalui Tingkat Motivasi Kerja Karyawan terhadap Tingkat Kinerja Karyawan dengan Koefisien Terstandarkan

Merujuk pada Gambar 8. dapat dirumuskan persamaan model pengukuran Pengaruh Kuat lemahnya Budaya Organisasi dan Tingkat
Kompensasi melalui Tingkat Motivasi Kerja Karyawan terhadap Tingkat Kinerja Karyawan seperti disajikan pada Tabel 3 


\section{Tabel 3}

Persamaan Model Pengukuran Pengaruh Budaya Organisasi dan Kompensasi Terhadap Motivasi Kerja serta Implikasinya terhadap Kinerja Karyawan

\begin{tabular}{|c|c|c|}
\hline Model Pengukuran Konstruk & Indikator & Persamaan Pengukuran \\
\hline \multirow{7}{*}{ Budaya Organisasi (X1) } & Inovasi dan pengambilan risiko $\left(\mathrm{X}_{11}\right)$ & 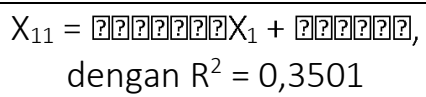 \\
\hline & Perhatian kepada detail $\left(\mathrm{X}_{12}\right)$ & 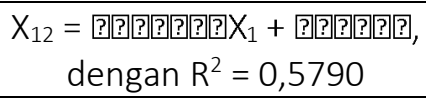 \\
\hline & Orientasi hasil $\left(\mathrm{X}_{13}\right)$ & 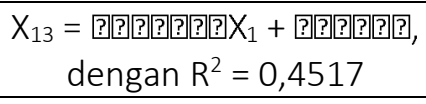 \\
\hline & Orientasi orang $\left(\mathrm{X}_{14}\right)$ & 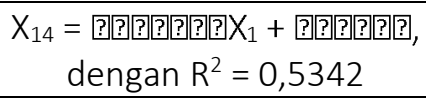 \\
\hline & Orientasi tim $\left(\mathrm{X}_{15}\right)$ & 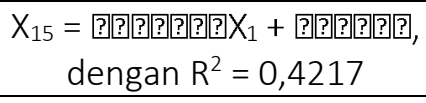 \\
\hline & Agresivitas $\left(\mathrm{X}_{16}\right)$ & 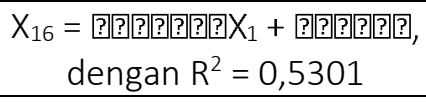 \\
\hline & Kemantapan $\left(\mathrm{X}_{17}\right)$ & 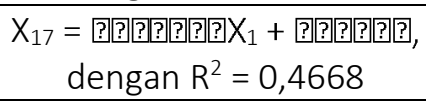 \\
\hline \multirow{3}{*}{ Kompensasi (X2) } & Keadilan Internal $\left(\mathrm{X}_{21}\right)$ & 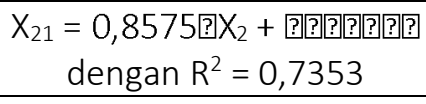 \\
\hline & Keadilan Eksternal ( $\left.\mathrm{X}_{22}\right)$ & $\begin{array}{c}\mathrm{X}_{22}=0,7552 \text { 和 } \\
\text { dengan } \mathrm{R}^{2}=0,5703\end{array}$ \\
\hline & Keadilan Individu $\left(\mathrm{X}_{23}\right)$ & 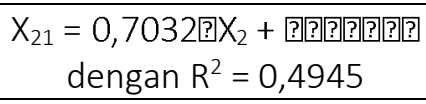 \\
\hline \multirow{3}{*}{ Motivasi kerja $(\mathrm{Y})$} & Kebutuhan akan prestasi $\left(\mathrm{Y}_{1}\right)$ & 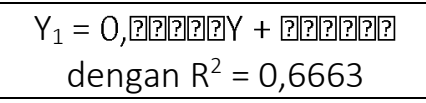 \\
\hline & Kebutuhan akan kekuasaan $\left(\mathrm{Y}_{2}\right)$ & 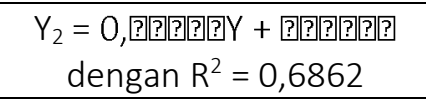 \\
\hline & Kebutuhan untuk berafiliasi $\left(Y_{3}\right)$ & 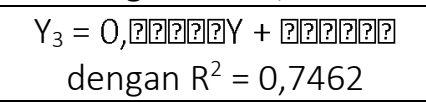 \\
\hline \multirow{3}{*}{ Kinerja Karyawan (Z) } & Disiplin $\left(Z_{1}\right)$ & 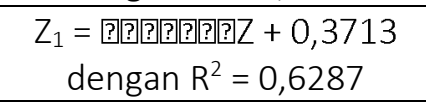 \\
\hline & Penyelesaian tugas $\left(Z_{2}\right)$ & 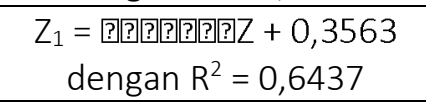 \\
\hline & Perilaku inovatif dan spontan $\left(Z_{3}\right)$ & 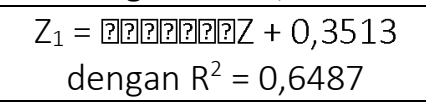 \\
\hline
\end{tabular}

\section{PEMBAHASAN}

$\begin{array}{lllr}\text { 5.1 } & \text { Pengaruh } & \text { Kuat lemahnya } & \text { Budaya } \\ \text { Organisasi } & \text { dan Tingkat Kompensasi } \\ \text { terhadap } & \text { Tingkat Motivasi Kerja } \\ \text { Karyawan } & & & \end{array}$

Hasil pengujian hipotesis menunjukkan bahwa besarnya pengaruh langsung dari kuat lemahnya budaya organisasi terhadap tingkat motivasi kerja adalah sebesar 0,2954 atau 8,73\%; pengaruh tingkat kompensasi terhadap tingkat motivasi kerja sebesar 0,6417 atau $41,18 \%$. Secara simultan, kedua variabel laten 
tersebut memiliki pengaruh (R2) sebesar 0,7592 atau $75,92 \%)$. Perhitungan ini menunjukkan bahwa pengaruh tingkat kompensasi terhadap tingkat motivasi kerja karyawan lebih besar dibandingkan dengan pengaruh kuat lemahnya budaya organisasi terhadap tingkat motivasi kerja karyawan di Bank BTN Cabang Bandung.

Tingginya pengaruh ini dapat dilihat dari validitas dan reliabilitas yang tinggi dari setiap indikator pada variabel-variabel eksogen. Variabel Kuat lemahnya Budaya Organisasi (X1) secara signifikan mempengaruhi Tingkat Motivasi Kerja Karyawan (Y) karena didorong oleh tingginya nilai setiap indikator variabel Kuat lemahnya Budaya Organisasi dalam membentuk variabel tersebut.

Dilihat dari indikator Inovasi dan Pengembangan Risiko, karyawan dinilai sudah memiliki keberanian untuk mengemukakan gagasan dengan segala risikonya. Lebih dari itu, motivasi karyawan dinilai sudah tinggi dalam menciptakan inovasi pekerjaan. Perusahaan juga dinilai telah memberikan peluang yang cukup bagi karyawan untuk berkreativitas dan berinovasi.

Dilihat dari indikator Perhatian pada Detail, karyawan dinilai memiliki kecermatan yang tinggi dalam penyelesaian masalah. Mereka juga dinilai mampu memahami uraian tugas. Perhatian karyawan dalam menghadapi berbagai situasi kerja dinilai sudah sangat tinggi. Sebagian besar karyawan dinilai memiliki ketelitian yang tinggi dalam menyelesaikan pekerjaan yang berkaitan dengan perbankan.

Dilihat dari indikator orientasi hasil, pimpinan Bank BTN sangat memperhatikan kelengkapan hasil kerja yang dilaksanakan oleh karyawan. Pimpinan Bank BTN juga memperhatikan kepuasan karyawan terhadap hasil pekerjaan yang dilakukan. Dalam hal ini, pimpinan Bank BTN mengutamakan hasil pekerjaan karyawan daripada proses pelaksanaan kerja, yaitu keutamaan hasil pekerjaan daripada masalah-masalah teknis.
Dilihat dari indikator orientasi orang, karyawan cukup dilibatkan dalam pengambilan keputusan, terutama yang berkaitan dengan kepentingan karyawan. Selain itu, pengambilan keputusan dinilai sudah sesuai dengan kondisi karyawan.

Dilihat dari indikator orientasi tim, terdapat komunikasi yang efektif antaranggota tim. Tim karyawan dinilai telah kompak dalam menghadapi berbagai masalah pekerjaan. Tanggung jawab tim dalam menyelesaikan pekerjaan dinilai sudah tinggi.

Dilihat dari indikator agresivitas, karyawan dinilai sudah bersikap pro-aktif dalam menghadapi berbagai situasi kerja. Mereka dinilai relatif memiliki kecekatan yang tinggi dalam menghadapi pekerjaan. Kompetensi karyawan dalam melakukan tugas dinilai sudah memadai.

Dilihat dari indikator kemantapan, karyawan dinilai memiliki konsistensi yang tinggi dalam menyelesaikan pekerjaan. Mereka sudah memahami visi dan misi organisasi. Dalam hal ini, pimpinan Bank mengapresiasi keterikatan karyawan terhadap peraturan yang ditetapkan.

Semua indikator kuat lemahnya budaya organisasi tersebut dapat mendukung tingginya tingkat motivasi kerja karyawan dalam bekerja. Hal ini sejalan dengan pendapat Nelson, D.L. dan Quick, J.C. (2008:393) bahwa satu fungsi dari budaya organisasi adalah memberikan identitas dan meningkatkan komitmen anggota organisasi. Ketika nilai-nilai perusahaan terinternalisasi pada karyawan, secara instrinsik mereka akan menemukan identitas diri sendiri dan identitas dengan sesama pekerja. Kondisi seperti ini dapat meningkatkan motivasi dan komitmen karyawan. Dengan demikian, budaya organisasi dapat mempengaruhi motivasi karyawan.

Variabel Tingkat Kompensasi (X2) juga secara signifikan mempengaruhi Tingkat Motivasi Kerja Karyawan (Y) karena didorong oleh tingginya nilai setiap indikator variabel 
Tingkat Kompensasi dalam membentuk variabel tersebut.

Dilihat dari indikator Keadilan Internal, karyawan menilai bahwa kompensasi yang diberikan Bank BTN kepada karyawan sudah sesuai dengan beban pekerjaan pada masingmasing level yang sama dalam organisasi. Kompensasi yang diberikan Bank BTN kepada karyawan juga sudah sesuai dengan tingkat jabatan pada masing-masing level yang sama dalam organisasi. Kompensasi yang diberikan Bank BTN kepada karyawan dinilai sudah sesuai dengan kondisi pekerjaan pada masing-masing level yang sama dalam organisasi. Kompensasi yang diberikan Bank BTN kepada karyawan dinilai sudah sesuai dengan kualifikasi pendidikan karyawan pada masing-masing level yang sama dalam organisasi. Keadilan internal ini juga dapat dilihat dari adanya kompensasi yang diberikan Bank BTN kepada karyawan yang sudah sesuai dengan kompetensi karyawan pada masing-masing level yang sama dalam organisasi.

Dilihat dari indikator Keadilan Eksternal, karyawan menilai bahwa kompensasi yang diberikan organisasi pada jabatan tertentu dibandingkan dengan organisasi lain pada jabatan yang sama. Demikian pula bahwa kompensasi yang diberikan Bank BTN kepada karyawan sesuai dengan peraturan perundangundangan yang berlaku di Indonesia.

Berkaitan dengan indikator Keadilan Individu, kompensasi yang diberikan Bank BTN kepada karyawan dinilai telah sesuai dengan prestasi kerja karyawan. Demikian pula bahwa kompensasi yang diberikan Bank BTN kepada karyawan sesuai dengan masa kerja karyawan.

Semua indikator dalam tingkat kompensasi tersebut dapat meningkatkan motivasi kerja pegawai. Hal ini sejalan dengan pendapat McLaughlin, D.J., (1991:59) mengemukakan bahwa sistem kompensasi yang buruk dapat melemahkan motivasi pegawai. Hal ini berarti bahwa sistem kompensasi yang baik dapat meningkatkan motivasi. Ivancevich, (dalam
Amos, T.L., et.al., 2009:311), menjelaskan kebijakan kompensasi dibutuhkan dalam organisasi apapun. Tujuan dari setiap fungsi kompensasi adalah untuk menciptakan suatu sistem imbalan yang memenuhi kebutuhan perusahaan dan karyawan. Hasil yang diharapkan adalah karyawan yang tertarik untuk bekerja dan termotivasi untuk melakukan pekerjaan dengan baik. Oleh karena itu menurut Amos, T.L., et.al. (2009:311) kompensasi harus dikelola secara efektif. Kompensasi merupakan komponen biaya terbesar bagi bisnis dan dapat mempengaruhi tidak hanya posisi kompetitif, tetapi juga dapat mempertahankan tenaga kerja.

\subsection{Pengaruh Kuat lemahnya Budaya Organisasi dan Tingkat Kompensasi melalui Tingkat Motivasi Kerja Karyawan terhadap Tingkat Kinerja Karyawan}

Hasil pengujian hipotesis menunjukkan bahwa besarnya pengaruh langsung dari kuat lemahnya budaya organisasi terhadap tingkat kinerja karyawan adalah sebesar 0,3175 atau 10,08\%; tingkat kompensasi terhadap tingkat kinerja karyawan sebesar 0,3334 atau 11,12\%; dan tingkat motivasi kerja terhadap tingkat kinerja karyawan sebesar 0,3702 atau 13,70\%. Secara simultan, ketiga variabel laten tersebut memiliki pengaruh (R2) terhadap Kinerja Karyawan sebesar 0,8758 atau 87,58\%. Perhitungan ini menunjukkan bahwa secara langsung pengaruh tingkat motivasi kerja terhadap tingkat kinerja karyawan lebih besar dibandingkan dengan pengaruh kuat lemahnya budaya organisasi atau tingkat motivasi kerja karyawan terhadap tingkat kinerja karyawan di Bank BTN Cabang Bandung. Namun demikian, perhitungan model struktural menunjukkan bahwa pengaruh total (langsung dan tidak langsung) dari variabel Kuat lemahnya Budaya Organisasi (X1) dan variabel Tingkat Kompensasi (X2) lebih besar daripada pengaruh langsung Tingkat Motivasi Kerja Karyawan (Y) terhadap 
Tingkat Kinerja Karyawan (Z). Hal tersebut menunjukkan bahwa tingginya tingkat motivasi kerja terhadap tingkat kinerja karyawan sangat ditentukan oleh adanya pengaruh kuat lemahnya budaya organisasi dan tingkat kompensasi.

Dalam hal ini, budaya organisasi dapat memberikan suasana yang dapat mendukung karyawan untuk dapat melakukan pekerjaan dengan baik. Hal ini sejalan dengan pendapat Robbins (2006:256) bahwa budaya organisasi yang dijalankan oleh jajaran karyawan dengan konsekuen dan konsisten dapat menciptakan kehidupan organisasi yang terbuka, karyawan bebas mengungkapkan pikiran dan perasaan, serta berpartisipasi dalam proses pengambilan keputusan manajerial. Semua ini akan memberikan pengaruh positif terhadap kinerja karyawan yang selanjutnya akan berpengaruh terhadap kinerja organisasi. Berdasarkan uraian di atas, budaya organisasi merupakan faktor yang dapat mempengaruhi kinerja karyawan. Jika seluruh faktor budaya organisasi tersebut melekat kuat dan bernilai positif, maka pengaruhnya akan signifikan terhadap kinerja karyawan, begitu juga sebaliknya.

Temuan penelitian menunjukkan bahwa semakin tinggi tingkat kompensasi, semakin tinggi pula kinerja karyawan. Tingkat kompensasi yang dipersepsi memadai dan adil oleh karyawan dapat mendorong karyawan untuk berkinerja secara lebih baik. Secara empiris, karyawan mempersepsi bahwa kompensasi yang diberikan oleh Bank BTN relatif adil dan memadai. Hal ini ditegaskan oleh Mathis, R.L., dan Jackson, J.H. (2012:171) yang mengemukakan bahwa kompensasi memiliki kaitan yang erat dengan kinerja individu, kelompok atau organisasi. Oleh karena itu, karyawan yang berkinerja lebih baik seharusnya menerima kompensasi lebih. Sims, R.R. (2007:272) menegaskan sistem penghargaan organisasi (kompensasi) adalah salah satu kekuatan yang paling dominan sebagai pendorong perilaku karyawan (kinerja). Selaras dengan pendapat tersebut Rivai, V. (2004:357) mengungkapkan bila kompensasi yang dirasakan oleh karyawan kurang, maka akan mengurangi kinerja, meningkatkan keluhan-keluhan penyebab mogok kerja dan mengarah pada tindakan-tindakan fisik dan psikologis, seperti meningkatnya derajat ketidakhadiran dan perputaran karyawan.

Secara empiris, tingkat motivasi kerja karyawan Bank BTN berpengaruh signifikan terhadap tingkat kinerja mereka. Kondisi ini menunjukkan bahwa motivasi kerja yang tinggi dapat mendorong karyawan untuk berkinerja lebih baik pula. Dalam hal ini, motivasi merupakan suatu determinan penting bagi kinerja individu. Hal ini sejalan dengan pendapat Sekaran (dalam Pattanayak, B., 2005:188) yang menyatakan bahwa kinerja yang tinggi akan muncul dari motivasi kerja yang tinggi, yang didorong oleh adanya sistem kompensasi yang adil

\section{KESIMPULAN}

Berdasarkan hasil analisis penelitian dan pembahasan pada Bab IV, diperoleh beberapa kesimpulan sebagai berikut.

1. Kuat lemahnya Budaya Organisasi dapat direfleksikan dan dibentuk oleh indikator Inovasi dan pengambilan risiko, Perhatian kepada detail, Orientasi hasil, Orientasi orang, Orientasi tim, Agresivitas, dan Kemantapan. Budaya Organisasi ini termasuk pada kategori kuat. Artinya nilainilai inti organisasi dipegang kuat oleh seluruh anggota organisasi, sehingga kondusif bagi karyawan Bank BTN Cabang Bandung untuk bekerja.

2. Tingkat Kompensasi Karyawan dapat direfleksikan dan dibentuk oleh indikator Keadilan Internal, Keadilan Eksternal, dan Keadilan Individu. Tingkat kompensasi karyawan termasuk pada kategori tinggi, sehingga dapat dikatakan bahwa Bank BTN 
Cabang Bandung telah memberikan kompensasi secara adil.

3. Tingkat Motivasi Kerja Karyawan dapat direfleksikan dan dibentuk oleh indikator Prestasi, Kekuasaan, dan Afiliasi. Tingkat motivasi kerja karyawan termasuk pada kategori tinggi, sehingga dapat dikatakan bahwa karyawan Bank BTN Cabang Bandung memiliki tingkat motivasi kerja yang tinggi.

4. Tingkat Kinerja Karyawan dapat direfleksikan dan dibentuk oleh indikator Disiplin, Penyelesaian Tugas, serta Perilaku Inovatif dan Spontan. Tingkat kinerja ini termasuk pada kategori tinggi, sehingga dapat dikatakan bahwa karyawan Bank BTN Cabang Bandung memiliki tingkat kinerja yang tinggi.

5. Kuat lemahnya budaya organisasi memiliki pengaruh positif dan signifikan terhadap tingkat motivasi kerja karyawan. Artinya, kuat lemahnya budaya organisasi merupakan faktor penting terhadap perubahan tingkat motivasi kerja karyawan.

6. Tingkat kompensasi memiliki pengaruh positif dan signifikan terhadap tingkat motivasi kerja karyawan. Artinya motivasi kerja karyawan dapat ditingkatkan melalui pemberian kompensasi yang adil.

7. Kuat lemahnya budaya organisasi memiliki pengaruh positif dan signifikan terhadap tingkat kinerja karyawan. Hal ini berarti bahwa tinggi rendahnya tingkat kinerja karyawan dapat dibentuk oleh kuat lemahnya budaya organisasi.

8. Tingkat kompensasi memiliki pengaruh positif dan signifikan terhadap tingkat kinerja karyawan. Dapat dikatakan bahwa kinerja karyawan dapat ditingkatkan melalui pemberian kompensasi yang adil.

9. Tingkat motivasi kerja karyawan memiliki pengaruh positif dan signifikan terhadap tingkat kinerja karyawan. Artinya, semakin tinggi motivasi karyawan, semakin tinggi juga kinerja karyawan.

\section{REKOMENDASI}

Berdasarkan kesimpulan hasil penelitian ini, dapat diusulkan beberapa saran bagi perusahaan dan bagi peneliti lain yang tertarik untuk mengkaji lebih jauh mengenai topik yang berkaitan dengan variabel yang digunakan dalam penelitian ini. Beberapa rekomendasi yang diajukan terkait hasil temuan penelitian dapat diuraikan sebagai berikut.

1. Indikator yang relatif rendah pada variabel Kuat lemahnya Budaya Organisasi adalah Inovasi dan Pengambilan Risiko. Oleh karena itu, pimpinan bank hendaknya dapat lebih mendorong karyawan agar lebih berani dalam mengemukakan gagasan, memotivasi karyawan dalam menciptakan inovasi pekerjaan, dan memberikan peluang karyawan untuk berkreativitas dan berinovasi.

2. Indikator yang relatif rendah pada variabel Tingkat Kompensasi adalah keadilan eksternal. Dalam hal ini, pimpinan bank diharapkan dapat lebih mempertimbangkan kesetaraan kompensasi yang diberikan organisasi pada jabatan tertentu dibandingkan dengan organisasi lain pada jabatan yang sama dan memperjelas kesesuaian kompensasi yang diberikan organisasi dengan peraturan perundang-undangan yang berlaku.

3. Indikator yang relatif rendah pada variabel Tingkat Motivasi Kerja adalah indikator kebutuhan akan kekuasaan. Oleh karena itu, pimpinan bank dapat memperkuat upaya karyawan dalam mempengaruhi dan mengendalikan orang lain, juga memberikan respon positif terhadap masalah-masalah organisasi.

4. Indikator yang relatif rendah pada variabel Tingkat Kinerja adalah indikator Perilaku Inovatif dan Spontan. Untuk itu, pimpinan diharapkan dapat memperkuat rasa pengabdian dan ketulusan karyawan 
terhadap pekerjaan, memberikan bimbingan agar karyawan tidak

\section{DAFTAR PUSTAKA}

Amos, T.L., et al. (2009). Human Resource Management. 3rd Edition. Juta and Company Ltd.

Aswathappa, K. (2007). Human Resource and Personnel Management. Foruth Edition. Tata McGraw-Hill Education.

Aswathappa, K., dan Dash, S. (2008). International Human Resource Management. Tata McGraw-Hill Education

Cardy, R.L. (2004). Performance Management: Concepts, Skills, and Exercises. M.E. Sharpe

Deb, T. (2009). Managing Human Resource and Industrial Relations. Excel Books India.

Divedi, R. K. (1995). Organizational Culture and Performance. New Delhi: M D Publications Pvt. Ltd.

Erasmus, B., and Schenk, H. (2008). South African Human Resource Management: Theory \& Practice. Fourth Edition. Cape Town: Juta and Company Ltd

Gibson, et al. (1996). Organisasi dan Manajemen, Perilaku Struktur dan Proses. Jakarta: Erlangga.

Hasibuan, Malayu S.P. (2000). Manajemen Sumber Daya Manusia. Edisi Revisi. Jakarta: Bumi Aksara.

Hoy, Wayne K. dan Miskel, Cecil G. (2001). Educational Administration Theory, Research, And Practice6th ed., International Edition, Singapore: McGrawHill Co.

Kono, T., dan Clegg, S.R. (1998). Transformation of Corporate Culture: Experiences of Japanese Enterprises. Walter de Gruyter
Luthans, Fred. (1998). Organization Behavior. International Edition, Sixth Edition, Mc Graw-Hill, Singapore.

Mathis, R.L., dan Jackson, J.H.,, (2012), Human Resource Management: Essential Perspectives. South Western: Cengage Learning

McLaughlin, D.J., (1991). Does Compensation Motivate Executives?.Foulkes, F.K. Executive Compensation: A Strategic Guide for the 1990s. USA: Harvard Bussiness School Prss

Nelson, D.L. dan Quick, J.C. (2008). Understanding Organizational Behavior. Cengage Learning EMEA

Pattanayak, B. (2005). Human Resource Management. 3rd Edition. PHI Learning Pvt.

Rahardja, Alice Tjandralila. (2004). “Hubungan Antara Komunikasi antar Pribadi Guru dan Motivasi Kerja Guru dengan Kinerja Guru SMUK BPK PENABUR Jakarta. Jurnal Pendidikan Penabur. III (3). [Online]. Tersedia: www.bpkpenabur.or.id/jurnal. [20 Oktober 2005]

Richard, M.A., et al. (2009). Employee Assistance Programs: Wellness/ Enhancement Programming. (4th Ed.). Charles C Thomas Publisher Ltd.

Rivai, Veitzal. (2004). Manajemen Sumber Daya manusia Untuk Perusahaan Dari Teori Ke Praktek. Jakarta: Raja Grafindo Persada.

Robbin, S.P. (2006). Perilaku Organisasi. Terjemahan. Edisi Kesepuluh. PT Indeks, Kekompok Gramedia.

Rusidi. (1989). Dasar-dasar Penelitian dalam Rangka Pengembangan IImu, Bandung: Program Pascasarjana Unpad.

Ruysseveldt, J.V, and Harzing, A.W. (2005). International Human Resource Management. London: Sage Publications Ltd. 
Sedarmayanti. (2009). Sumber Daya Manusia dan Produktivitas Kerja. Bandung: CV Mandar Maju.

Simamora, H. (2004). Manajemen Sumber Daya Manusia Edisi III. Yogyakarta: STIE YKPN

Sims, R.R. (2007). Human Resource Management: Contemporary Issues, Challenges, and Opportunities. Information Age Publishing, Inc: USA

Umar, H. (2003) Panduan Mahasiswa untuk Melaksanakan Riset Dilengkapi Contoh Proposal dan Hasil Riset Bidang Manajemen dan Akuntansi. Jakarta: PT Gramedia Pustaka Utama

Williams, R.S., (2006). Managing Employee Performance: Design and Implementation in Organizations: Psychology at Work Series. Thomson Learning.

Winardi. (2002). Motivasi dan Pemotivasian dalam Manajemen. Jakarta: PT Raja Grafindo Persada

Yuniarsih, Tjutju dan Suwatno. (2008). Manajemen Sumber Daya Manusia Teori, Aplikasi dan Isu Penelitian, Bandung: Alfabeta. 